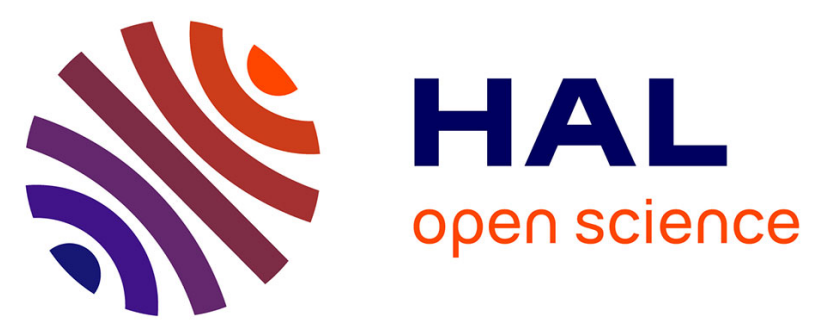

\title{
What will be the consequences of climate change on soft wheat in Normandy (France) in 2050-2100? Prospective impact study based on ALADIN-Climate model
}

François Beauvais, Olivier Cantat, Philippe Madeline, Patrick Le Gouée, Sophie Brunel-Muguet, Mohand Medjkane

\section{To cite this version:}

François Beauvais, Olivier Cantat, Philippe Madeline, Patrick Le Gouée, Sophie Brunel-Muguet, et al. What will be the consequences of climate change on soft wheat in Normandy (France) in 20502100 ? Prospective impact study based on ALADIN-Climate model. European Geosciences Union General assembly, May 2020, Vienne, Austria. hal-02886448

\section{HAL Id: hal-02886448 \\ https://hal.science/hal-02886448}

Submitted on 1 Jul 2020

HAL is a multi-disciplinary open access archive for the deposit and dissemination of scientific research documents, whether they are published or not. The documents may come from teaching and research institutions in France or abroad, or from public or private research centers.
L'archive ouverte pluridisciplinaire HAL, est destinée au dépôt et à la diffusion de documents scientifiques de niveau recherche, publiés ou non, émanant des établissements d'enseignement et de recherche français ou étrangers, des laboratoires publics ou privés. 
What will be the consequences of climate change on soft wheat in Normandy (France) in $2050-2100 ?$ Prospective impact study based on ALADIN-Climate model

François BEAUVAIS ${ }^{1,2}$, Olivier CANTAT ${ }^{1}$, Philippe MADELINE², Patrick LE GOUÉE ${ }^{1}$, Sophie BRUNEL-MUGUET ${ }^{3}$, Mohand MEDJKANE ${ }^{1,4}$

1 Normandie Univ, UNICAEN, CNRS, LETG, 14000

\section{Introduction}

France is the fifth largest producer worldwide of soft wheat. Every year over 35 million tons of wheat are harvested (average 2011-2017, data from France AgriMer) on the territory. Hence, the cereal sector occupies a key place in the French agricultural economy. Normandy makes a significant contribution to this outcome with
million tons. Most of the production is exported to Maghreb and China via ports located in Rouen and Caen.

However, because of its high dependence on atmospheric conditions, wheat production is vulnerable to climate change. Since the mid-1990s, a stagnation of yield has already been observed. According to the agronomists, climate change is responsible for that : Water deficit during stem elongation and scalding days during grain filling
cling (Gate, 2009 ; Brisson et al., 2010).

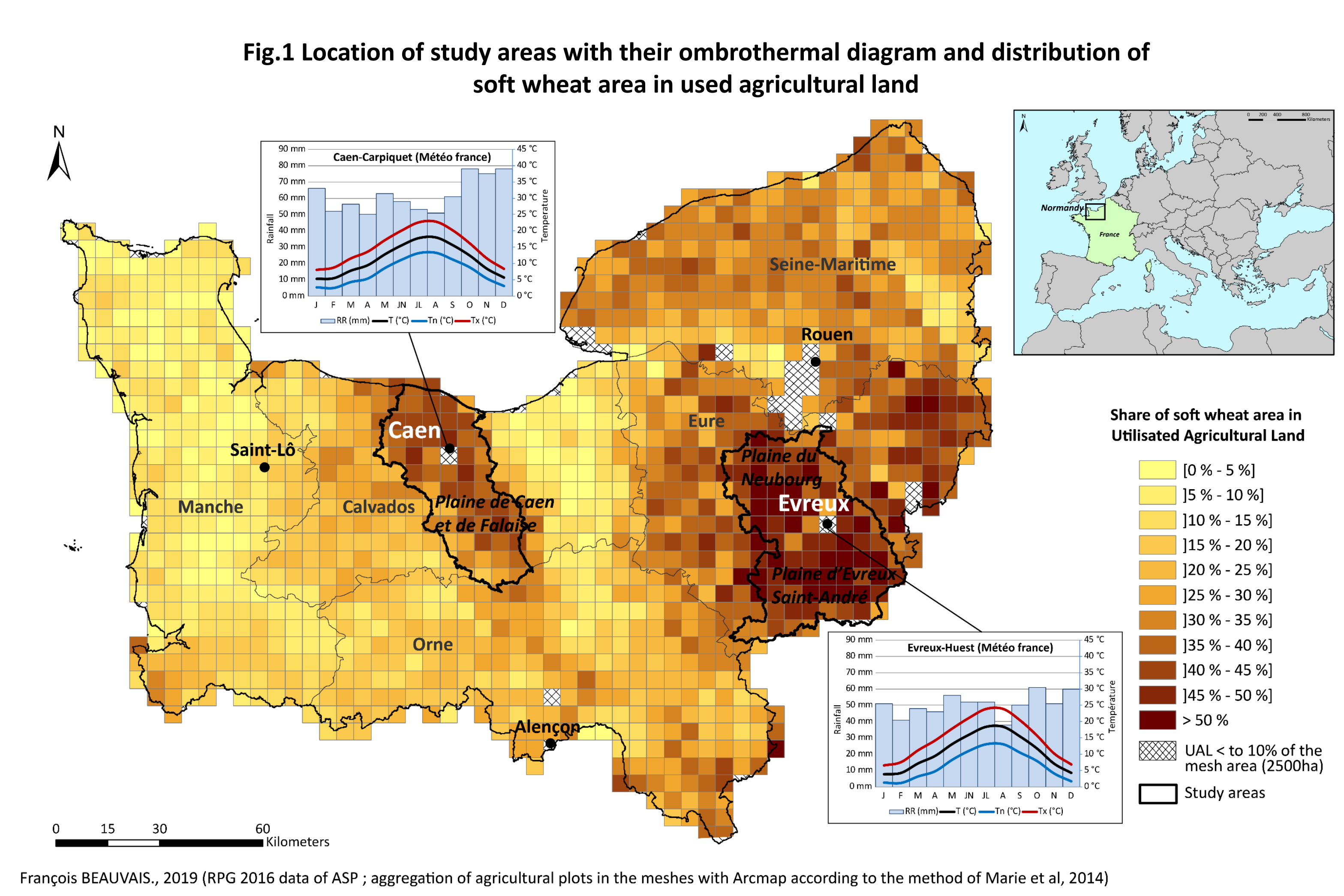

\section{Study areas}

This study illustrates 2 agricultural plains containing open fields in Normandy, North-West of France. occupies more than $50 \%$ of the
oction agricultural land (fig.1 ):

- Caen plaine which is under the influence of an oceanic climate.

$\left(11,2^{\circ} \mathrm{C} ;\right.$; $740 \mathrm{~mm}$ rainfalls; 32 frost days and 23
hot days on climate normal $1981-2010)$

Evreux plaine where climate is slightly more continental.

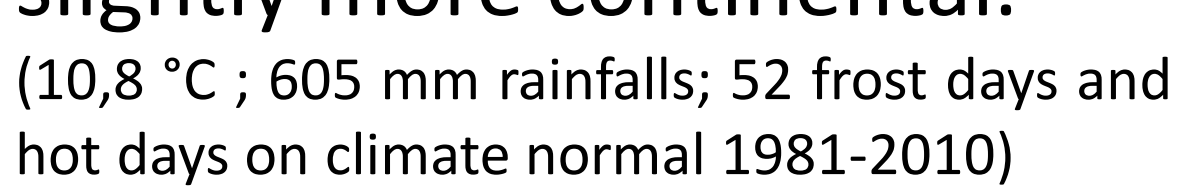

\section{Climate context : observation and projection}

Normandy climate is favourable to wheat production. Proximity to the English Channe heat wav. Hower, risk of water deficits hear waves. However, risk of water deficits in spring is not excluded, especially where the soll is thiner. But climate is changing. The $0.8^{\circ} \mathrm{C}$ increase betwe 1981-2010 climate norma (fig. 2) It is going on since the temperature of the is going years is $0.5^{\circ} \mathrm{C}$ above of 1981-2010's normat. On the other hand, there is no significan trend concerning cumulative rainfall.
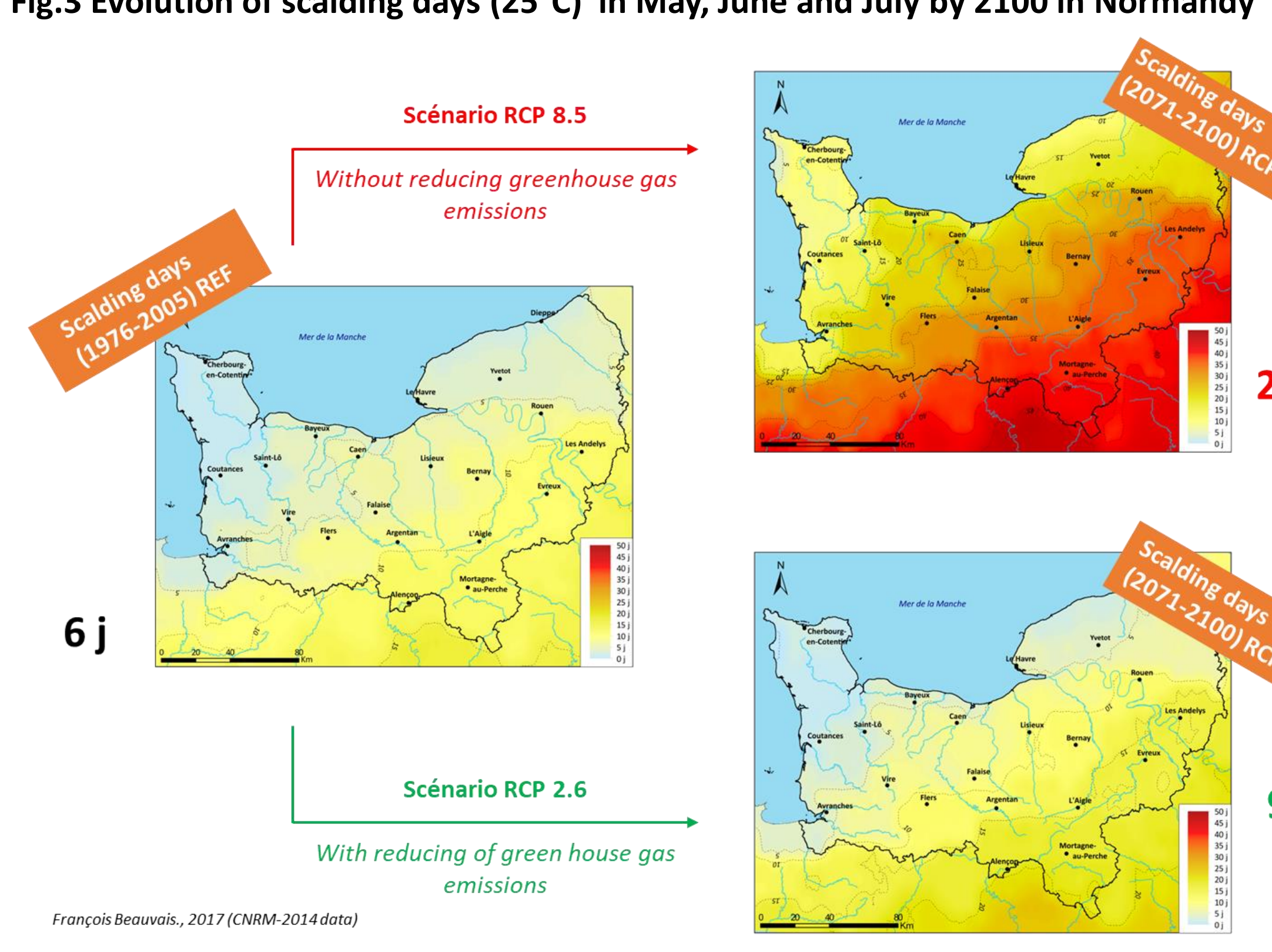

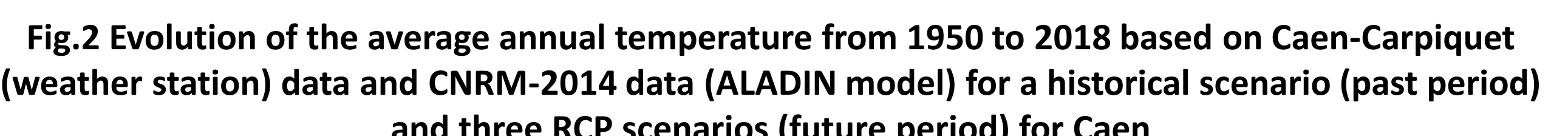

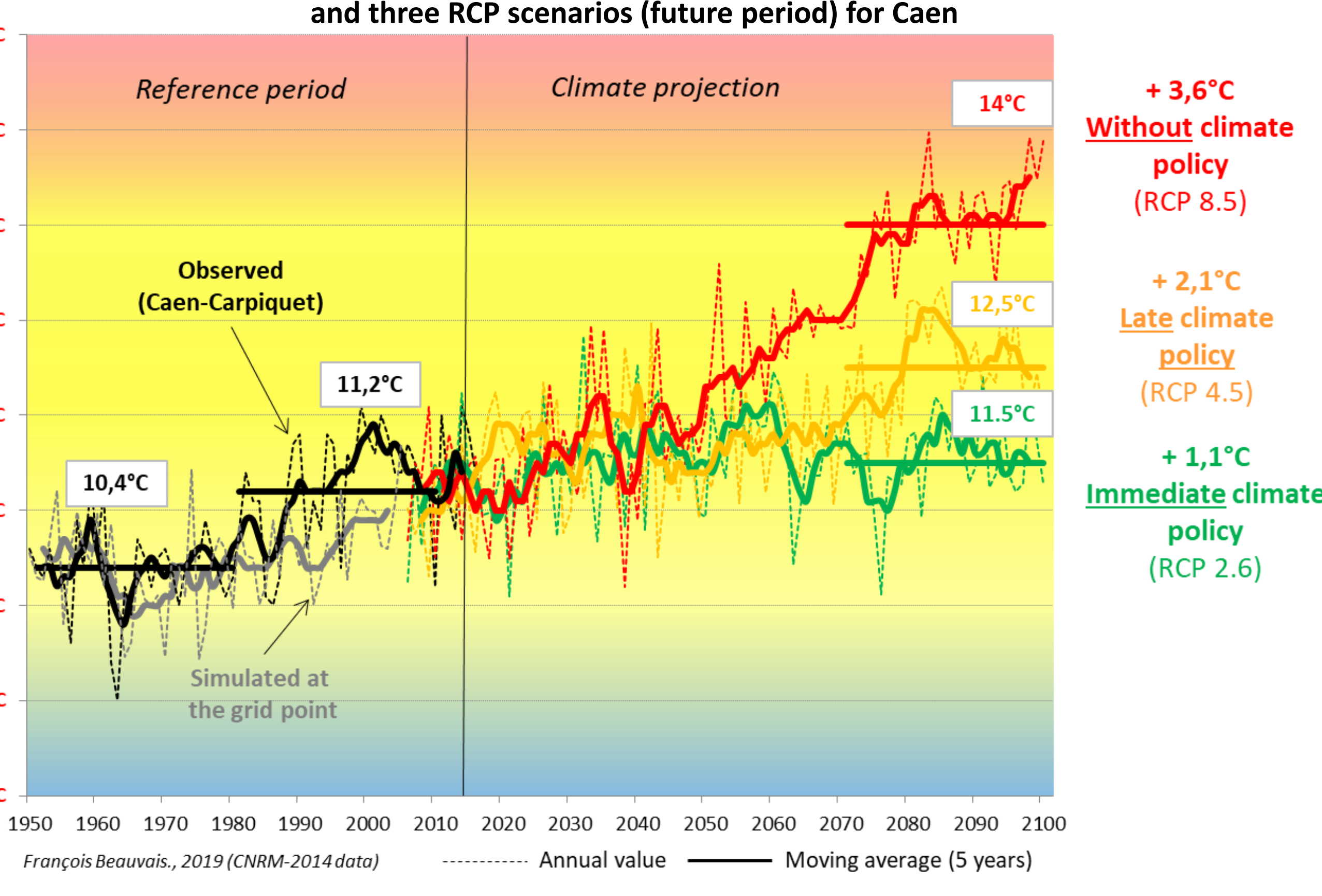

The intent of this study is to present what would be the climatic conditions for soft wheat in 2050 and 2100 and to compare them with the reference period (19762005). The climatic data is extracted from ALADINClimate (data from CNRM-2014 with a spatial resolution of $8 \times 8 \mathrm{~km}$ ) concerning three RCP scenarios of IPCC, available on the "Drias Les futurs du climat" website. Without any reduction of global greenhouse gas emissions, temperature could rise by as much as $+3.6^{\circ} \mathrm{C}$ (fig.2). The number of hot days over May, June and July would be multiplied by four (fig.3). At the same time, cumulative rainfall would decrease by $-13 \%$ in spring and $-30 \%$ in summer. Given the stagnation in yields already observed, this is alarming.

3. Method : bioclimatic approach

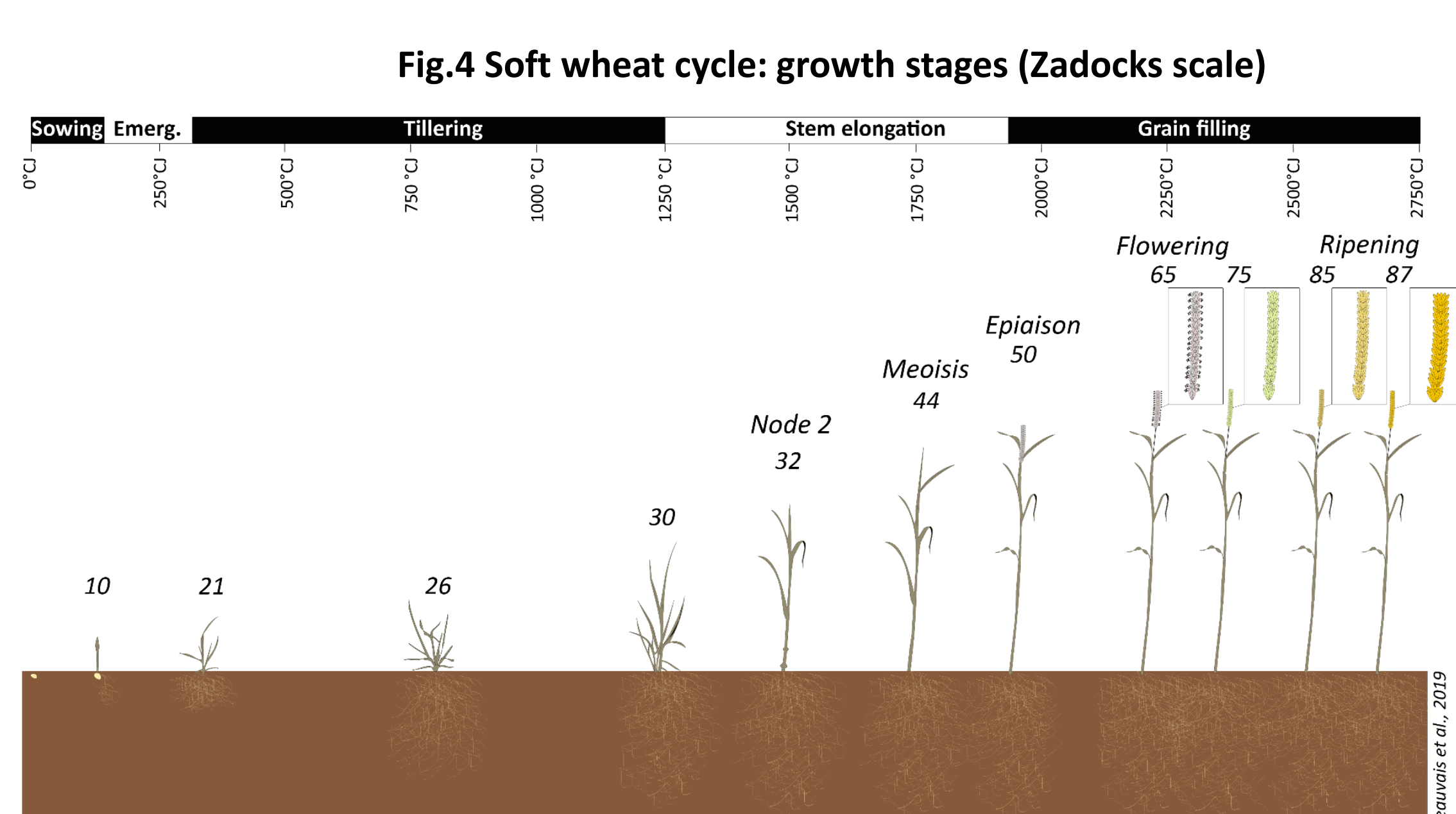

4. Results

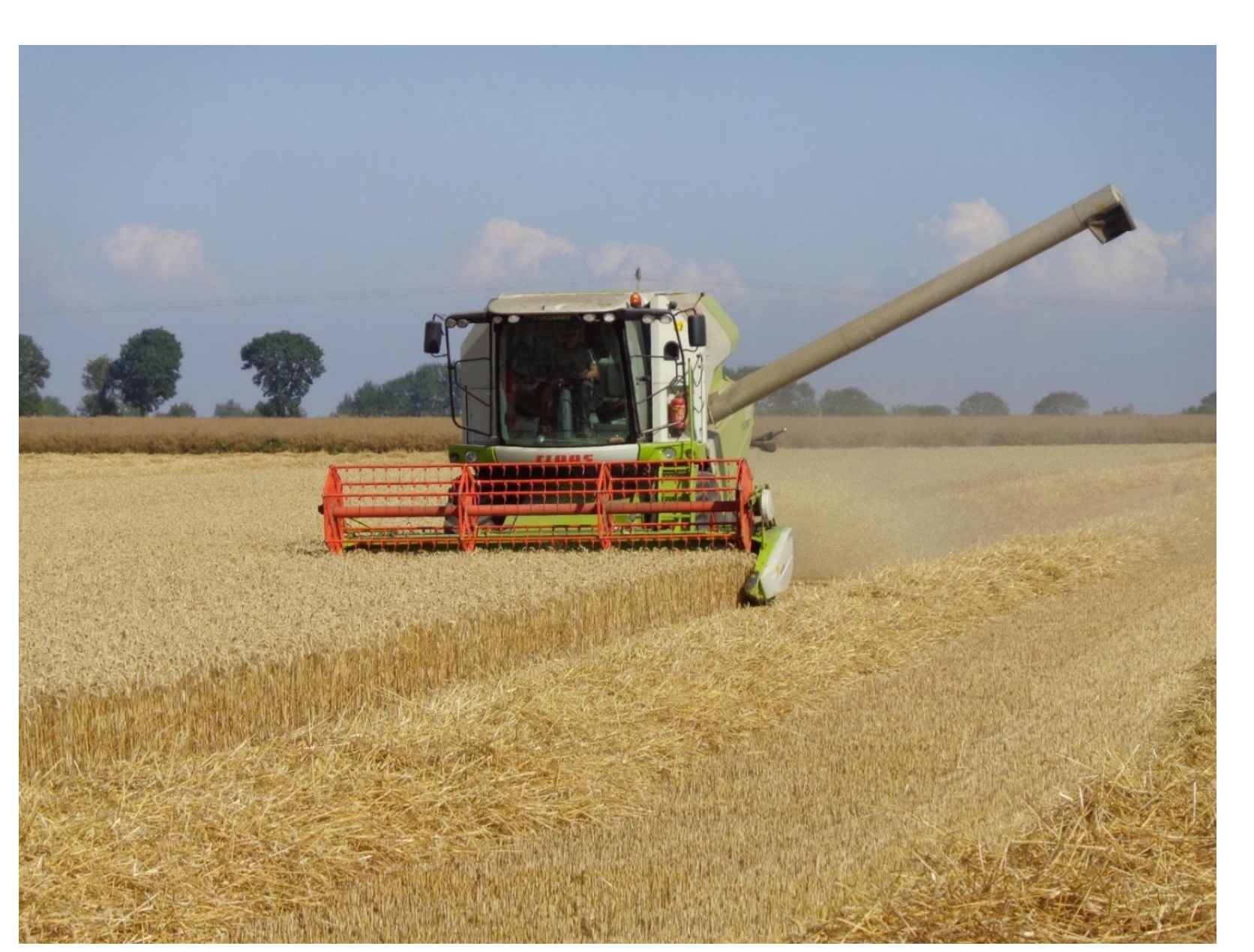

Phenology anticipation : harvest in early july ?

In the reference period the physiological maturity of wheat occurs at the end of July, which corresponds to harvests in early August. In the context of a pronounced climate change, along with unchanged sowing dates by 2050 and hence to ancrease in temperatures would lead to shorten the crop cycle, and maturity would show up in mid-July for the thre in short term, physiological to a two-weeks cycle reduction. In the long term, with the RCP 4.5 scenario, maturity would occur at the beginning of July and at the end of June for the warmest scenario. So in 2100 the wheat harvest could take place at the beginning of July.

What will be the consequences?

Consequently, there would be a shorter overlap between the end of the crop cycle and the summer period, usually characterized by heat waves and water stress events which are expected to occur more often. Thus, high temperature triggered scalding wouldn't be observed as much as expected and the cumulated water limitation would be also lower (fig.5.A,B,C,D). The impact on grain filling would be no heavier than at present. However, because of this precocity, emerging consequences might be expected regarding deleterious effects of lower temperatures during meiosis (tab.1), and decrease of solar radiation at the onset of stem elongation (fig.5.G,H). Mild winters would also reduce the number of

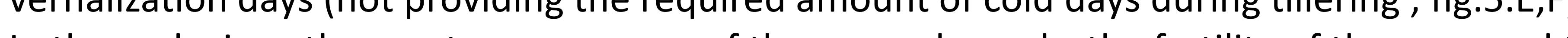

In the end, given the greater occurrence of these new hazards, the fertility of the ears, and the growth and flowering of the wheat could be impacted.

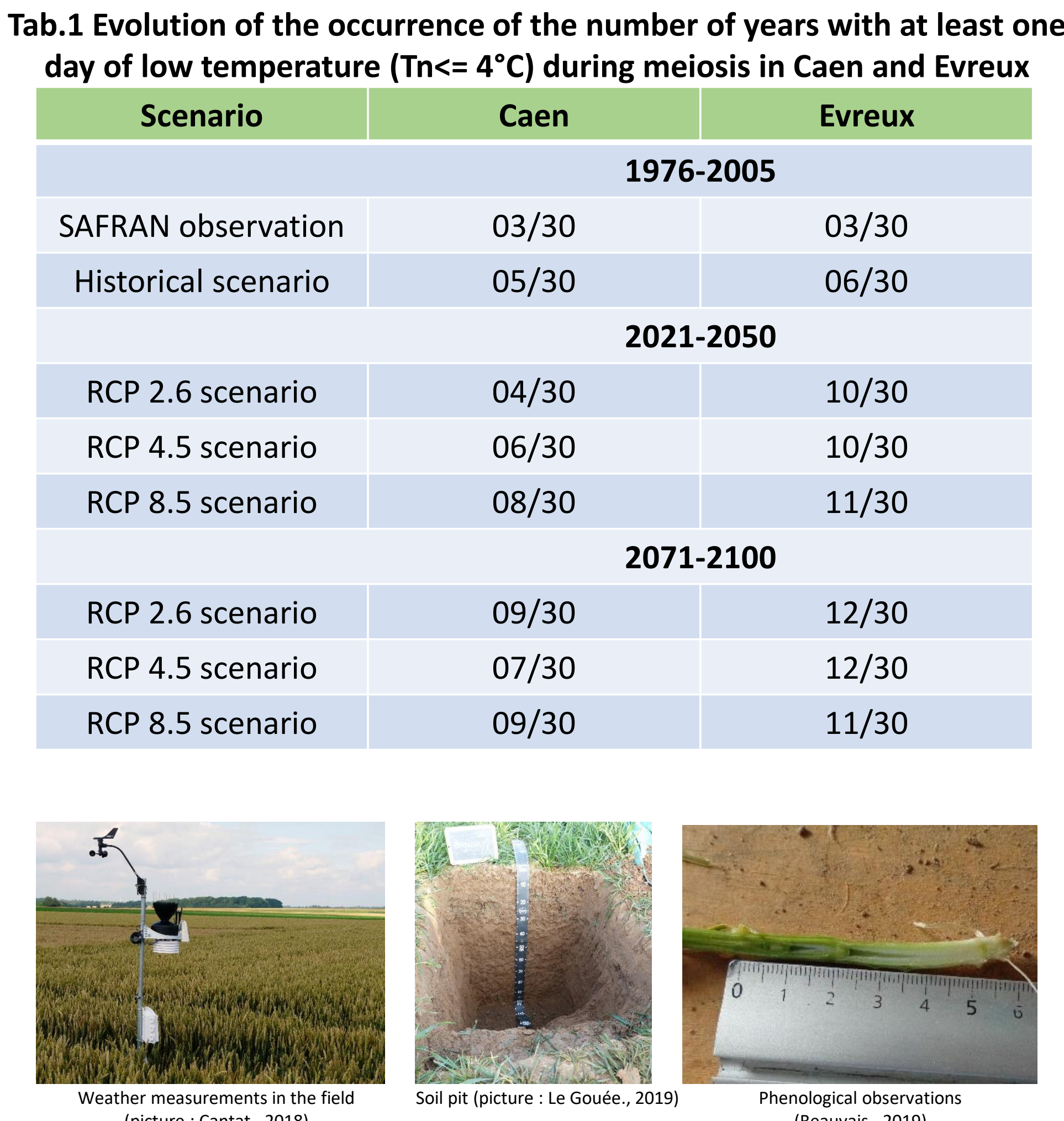

5. Limits and perspectives The agrcultural areas studied are flat and open_fields. Consequently, the $8 \times 8 \mathrm{~km}$ climate model resolution is apposite. Nevertheless the spatial variability of temperatures (fig.6) should be considered (example of sea breeze and opography effects on a local scale). Expeninental temperature measurements (in the field and under controlled conditions) at several geographical scales.

Integrate the mechanisms governing plant physiology and use a crop model to estimate yield potential.

Develop a field survey for farmers to estimate their adaptation capacity based on their observations, perceptions and understanding of climate change.

\section{Conclusion}
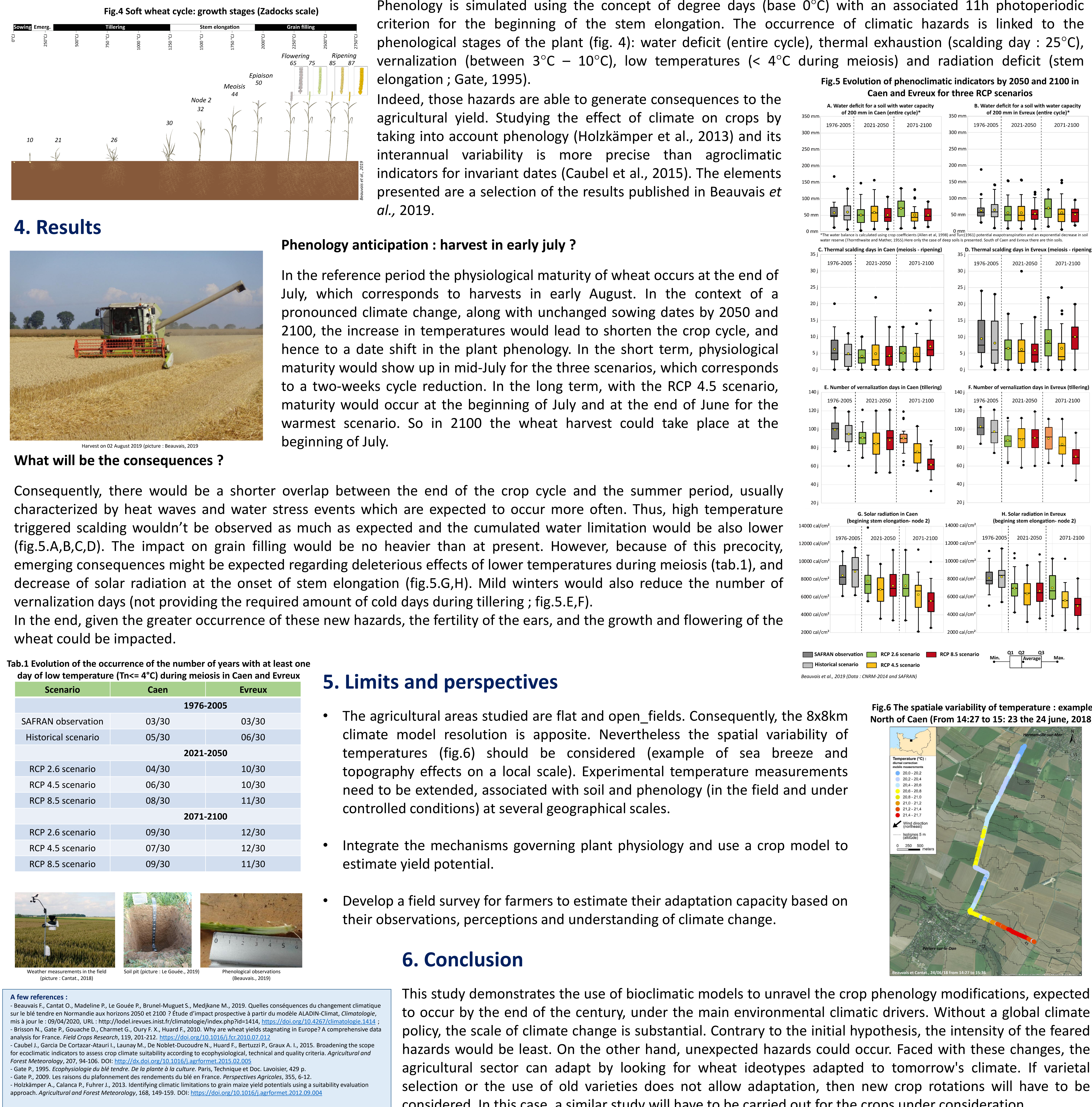

This study demostates the use of bioclimatic models to unravel the crop phe

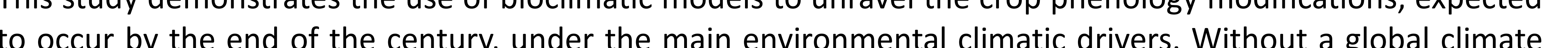
policy the scale of climate change is substantial. Contrary to the initial hypothesis, the intensity of the feared hazards would be least. On the other hand, unexpected hazards could occur. Faced with these changes, the agricultural sector can adapt by looking for wheat ideotypes adapted to tomorrow's climate. If varietal election or the use of old varieties does not allow adaptation, then new crop rotations will have to be considered. In this case, a similar study will have to be carried out for the crops under consideration.

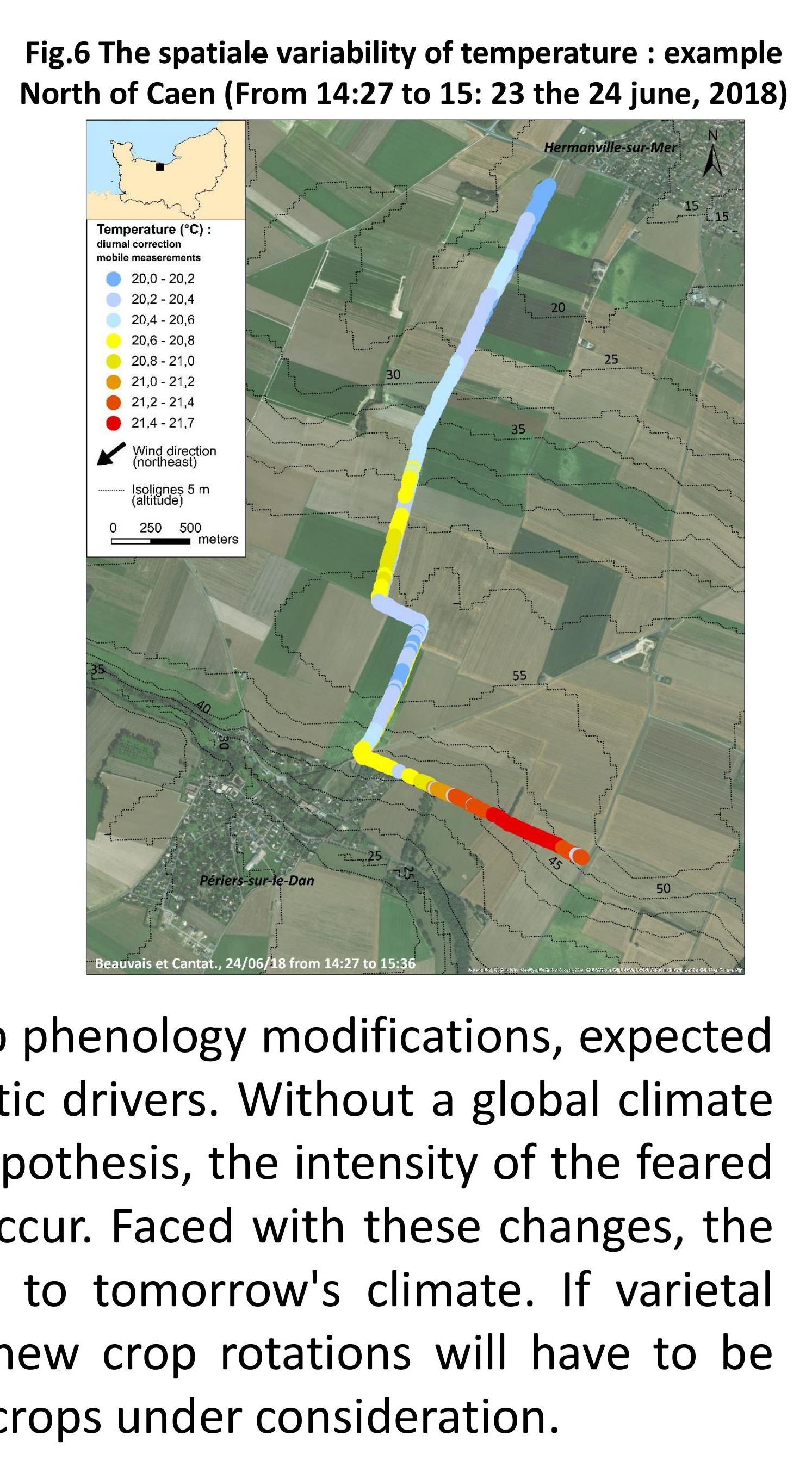

